\title{
Genetiese manipulering van die gis Saccharomyces cerevisiae betreffende polisakkariedbenutting
}

\author{
I.S. Pretorius \\ Departement Mikrobiologie en Instituut vir Biotegnologie, Universiteit van Stellenbosch, Stellenbosch 7600
}

Die gis Saccharomyces cerevisiae word wêreldwyd as die belangrikste kommersiële mikro-organisme bestempel en geniet sogenaamde ABAV-status (Algemeen Beskou As Veilig) weens dié gis se eeue lange verbintenis met voedselproduksie (bv. brood, wyn, bier, proteienaanvulling en geurstowwe). Hierbenewens is $S$. cerevisiae ook ongetwyfeld die populêrste eksperimentele model vir molekulêre en klassieke genetiese studies. Gisselle is net so maklik hanteerbaar soos prokariotiese selle (bakterieë) en toon ook belangrike sellulêre en molekulêre ooreenkomste met selle van hoër eukariote (plante en diere). Boonop reproduseer $S$. cerevisiae sowel geslagtelik as ongeslagtelik (in die haploïede en diploïede fase), wat dit 'n ideale sisteem vir Mendelse oorerwingsontledings maak. S. cerevisiae is dus die werkesel vir biotegnologiese toepassings sowel as fundamentele navorsing.

Polisakkariede soos stysel, pektien en sellulose is belangrike biologies-hernieubare hulpbronne. Insgelyks is die molekulêre regulering van gene, wat vir ekstrasellulêre polisakkaried-afbrekende ensieme kodeer, hoegenaamd nie ontrafel nie. Die doel van hierdie navorsingsprogram is dus (i) om die transkripsionele beheer van gene wat by polisakkariedmetabolisme betrokke is, te bestudeer en (ii) om die genetiese potensiaal van S. cerevisiae sodanig uit te brei dat dit in staat sal wees om polisakkaried-bevattende landbougewasse (bv. mielies, graansorghum, vrugte en suikerriet) as substraat te benut vir die produksie van kommersieel belangrike kommoditeite (bv. enkelselproteien, etanol, versoeters en ensieme).

Reguleringselemente vir optimale uitdrukking van heteroloë gene en uitskeidingseine vir maksimale ensiemuitskeiding is die sleutel tot hierdie projek. Die molekulêre besonderhede en fynstruktuur van verskeie reguleringselemente is met behulp van restriksie-endonuklease kartering, DNA-volgordebepaling en delesie-analises ontrafel. Verskillende kombinasies van promotor- $\left(A D C I_{p}\right.$, amy, $M F \alpha l_{p}$ en $S T A 2_{p}$ ) en leiervolgordes ( $a m y_{p}, M F \alpha I_{p}$, pelE, $S T A 2_{\text {, }}$ en $S U C 2_{\text {r }}$ ) is deur middel van PKR-(polimerasekettingreaksie-) amplifikasie geskep en geëvalueer ten opsigte van hul vermoë om effektiewe geenuitdrukking en ensiemuitskeiding in S. cerevisiae te bewerkstellig. Die gis $A D C I$ promotor en $M F \alpha l$-sekresiesein is as die effektiefste kombinasie bewys en is sodanig gekonstrueer dat die promotor se werking konstitutief is en nie aan enige onderdrukking onderhewig is nie. Hierdie beheereenheid is gekies om vooraan drie heteroloë geenkassette wat onderskeidelik vir amilases, pektinases en sellulases kodeer, te kloneer.

Stysel bestaan uit lineêre (amilose) en vertakte (amilopektien) glukosepolimere wat deur $\alpha$-amilases, glukoamilases en onttakingsensieme (bv. pullulanases en isoamilases) gehidroliseer kan word. Die $\alpha$-amilase-geen ( $a m y$ ) van die bakterium Bacillus amyloliquefaciens, die glukoamilase-geen (STA2) van die gis Saccharomyces diastaticus en die pullulanase-geen ( $p u l$ ) van die bakterium Klebsiella pneumoniae is gekloneer en gekarakteriseer. Die STA2- en amy-gene is afsonderlik en gesamentlik onder hul oorspronklike reguleringselemente in $S$. cerevisiae uitgedruk. Die $p u l$-geen kon nie onder die oorspronklike bakteriese beheerseine in $S$. cerevisiae uitgedruk word nie. Tans word die amy-, STA2-en pul-gene in-leesraam agteraan die $A D C I_{p}$ $M F \alpha l_{s}$ beheereenheid gekloneer voordat hierdie amilasekasset na industriële rasse van $S$. cerevisice getransformeer word.

Pektiene bestaan hoofsaaklik uit galakturonosiel-, rhamnosiel-, arabinosiel- en galaktosielresidue. Hierdie heteropolisakkariede word deur pektienesterases en pektiendepolimerases (hidrolases en liases) afgebreek. Poligalakturonase splits die glikosidiese bindings van pektiese stowwe hidrolities, terwyl pektaatliases dié bande deur $\beta$ eliminasie breek. Die pektaatliase- (pelE-) en poligalakturonase- (peh-) gene is onderskeidelik uit die bakterieë Erwinia chrysanthemi en E. carotovora gekloneer, gekarakteriseer en individueel onder die $A D C I_{p}-M F \alpha l_{s}$ beheereenheid in $S$. cerevisiae uitgedruk. Hierdie $A D C I_{p}$ $M F \alpha l_{s}$ beheerde pelE- en peh-gene sal nou gesamentlik as 'n pektinasekasset na kommersiële rasse van $S$. cerevisiae getransformeer word.

Sellulose bestaan uit lineêre $\beta$-glukosepolimere wat deur endoglukanases, eksoglukanases en sellobiohidrolases afgebreek kan word. Die endo-1, 3-1, 4- $\beta$-D-glukanasegeen (beg) van die bakterium Bacillus subtilis is gekloneer, gekarakteriseer en word tans in-leesraam aan die $A D C l_{p}-M F \alpha l_{s}$ -beheereenheid gekoppel. Daarna sal die glukanase(egll-) en sellobiohidrolase- (cbhl-) gene van die fungus Trichoderma reese $i$ by die beg-geen gevoeg word ten einde 'n sellulasekasset na $S$. cerevisiae oor te dra.

Kunsmatige minichromosome is reeds geskep waarin een of meer van hierdie drie geenkassette geplaas sal word. Industriële rasse van $S$. cerevisiae waarin hierdie minichromosome geïnkorporeer is, behoort dan in staat te wees om die bio-omsetting van polisakkariedryke substrate effektief deur te voer. 


\title{
Konsentrasies van swaar metale in natuurlike en behandelde rioolwater as moontlike bedreiging vir omgewingsgesondheid
}

\author{
D.J. van den Heever en B.J. Frey \\ Departement Omgewingswetenskappe, Technikon OVS, Privaat sak X20539, Bloemfontein 9300
}

Swaar metale kom wydverspreid in water voor en neig om in die weefsel van lewende organismes te akkumuleer. Behandelde riool water en natuurlike damwater is ondersoek vir die teenwoordigheid van swaar metale ten einde te bepaal of die konsentrasies teenwoordig enige gesondheidsgevaar vir die mens of vis inhou.

Die resultate van die studie is vergelyk met kwaliteitskriteria van die US Environmental Protection Agency (EPA) en die Wêreldgesondheidorganisasie (WGO), wat ontwerp is om 'n akwasisteem vir die hoër gebruike van water te onderhou. Die kwaliteitskriteria is ontwerp om langtermynbeskerming te bied, maar daar mag 'n gesondheidsgevaar vir die mens ontstaan wanneer waterorganismes met 'n toksiese residu verbruik word.

Watermonsters is versamel in $2 l$-hoëdigtheidspolietileenbottels by die oppervlak, middel en bodem van die waterbron.

Met die voorbereiding van die monsters is dit afsonderlik deurno. 2 Whatmann-filtreerpapier gefilter om vastestowwe te verwyder. Analise van monsters vir swaar metale is uitgevoer met 'n model 3410 ICP-spektrometer wat deur middel van emissiespektroskopie 'n vinnige, sensitiewe en gerieflike metode verskaf vir die bepaling van metale in water- en afvalwatermonsters.

Die fisiese eienskappe van die water is met ' $n$ Hannawatertoetsmeter tydens elke monsterneming by elke lokaliteit bepaal.

Die $\mathrm{pH}$ van die watermonsters het voldoen aan die voorgestelde kriteria wat strek tussen 6,5-9. Die hardheid van die water, waarsonder die toksisiteit van swaar metale in water nie beoordeel kan word nie, was tussen 100 en $150 \mathrm{mg} / \mathrm{l}$.

Ysterkonsentrasies in vis- en watermonsters het aan alle standaarde voldoen. Dit was onder die aanbevole EPA- en WGO-standaard vir drinkwater van $0,3 \mathrm{mg} / l$, terwyl die damwater hierdie vlak gedurende Maart en Mei oorskry het met onderskeidelik 0,5933 en $0,3866 \mathrm{mg} / l$.
Alle konsentrasies sink wat in monsters van beide lokaliteite gevind is, was onder die aanbevole EPA-standaard van $5 \mathrm{mg} / \mathrm{l}$. Die WGO beveel ook aan dat drinkwater nie meer as $5 \mathrm{mg} / \mathrm{l}$ sink moet bevat nie. 'n Gemiddelde konsentrasie sink van $0,00483 \mathrm{mg} / \mathrm{g}$ is in visweefsel gevind met die hoogste konsentrasie van $0,0064 \mathrm{mg} / \mathrm{g}$ in die maag van die vis.

Aluminiumkonsentrasies in natuurlike damwater was hoër as die WGO-standaard van $0,2 \mathrm{mg} / \mathrm{l}$ en mag moontlik verkleuring van die water veroorsaak. Lood was gemeet in onbeduidende konsentrasies, behalwe vir natuurlike damwater gedurende Februarie 1991. Die enkele hoë voorkoms van dié metaal mag 'n toksiese gevaar vir mens en dier inhou en is moontlik veroorsaak deur afwassing van deurdringende areas tydens reëntoestande.

Mangaan het aan die kriteria van $0,1 \mathrm{mg} / \mathrm{l}$ soos voorgestel deur die WGO voldoen. Onbeduidende hoeveelhede kwik is tydens die studie gemeet en word dus nie vermeld nie.

Chroom is slegs gedurende Januarie in watermonsters gevind, maar slegs in baie lae konsentrasies. Die EPAkriterium van $1,0 \mathrm{mg} / l$ vir varswatervislewe is nie oorskry nie, alhoewel die konsentrasies gevind in natuurlike damwater bykans twee maal so hoog soos dié in behandelde rioolwater was. Hierdie tendens mag te wyte wees aan die storting van afval vanaf omliggende Derdewêreldse nedersettings.

Die resultate dui verder daarop dat behandelde rioolwater geskik mag wees om vis in aan te hou, aangesien gemete konsentrasies hierin laer is as in natuurlike damwater. Hierdie aanname is slegs geldig met betrekking tot swaar metale in die water en sluit kontaminasie deur mikroorganismes en gechloreerde koolwaterstowwe uit. Wanneer 'n ekostelselbenadering met betrekking tot visse in afvalwater gevolg word, kan dit lei tot die veilige en gesonde verbouing van voedsel in habitatte van hierdie aard.

\section{Plasmafibrinogeen van Suid-Afrikaners}

\author{
H.H. Vorster, A. Kruger, J.C. Jerling, C.S. Venter, F.B. Mia, N. Silvis en W.J.H. Vermaak \\ Voedingsnavorsingsgroep, Potchefstroomse Universiteit vir CHO, Potchefstroom 2520
}

Plasmafibrinogeen is 'n glikoproteien wat deur die lewer gesintetiseer word. Dit is 'n akute-faseproteien en speel 'n sentrale rol in hemostase en die handhawing van bloedviskositeit. Verskeie epidemiologiese, kliniese en eksperimentele studies het aangetoon dat verhoogde plasmafibrinogeen 'n belangrike risikofaktor is vir die ontwikkeling van koronêre hartvaatsiektes (KHS), miokardiale infarksie en beroerte. Die plasmafibrinogeenvlakke van SuidAfrikaanse bevolkingsgroepe, wat groot verskille in die voorkoms van KHS toon, is nie bekend nie.

Die doel van hierdie studie was om plasmafibrinogeen van groepe blankes, Indiërs en bruin en swart mense te meet en 
met ander risikofaktore van KHS te korreleer. Fibrinogeen is in sitraatplasma $(1: 9, \mathrm{v} / \mathrm{v})$ van ongeveer 1400 gesonde, vastende proefpersone en 100 diabetes mellitus-pasiënte met'n gewysigde stollingsmetode van Clauss (Behringwerke, Duitsland) bepaal.

In ooreenstemming met die literatuur is gevind dat diabetes mellitus, die rookgewoonte en oorgewig met verhoogde fibrinogeenvlakke geassosieer word. Die resultate het verder getoon dat verwestering swartes se fibrinogeenvlakke mag verhoog, dat Indiërjeugdiges betekenisvol hoër vlakke as blankes van dieselfde ouderdom gehad het, en dat gesonde, blanke bejaardes in Potchefstroom se fibrinogeenwaardes aansienlik laer was as gepubliseerde waardes vir bejaardes. Die betekenisvolle positiewe korrelasies wat tussen fibrinogeen en oorgewig, serumcholesterol, -trigliseriede en -insulien verkry is, en die betekenisvolle negatiewe korrelasies tussen fibrinogeen en hoëdigtheidslipoproteïencholesterol, het aanduidings verskaf dat verhoogde plasmafibrinogeen moontlik deel van die androïede-obesiteitsindroom mag wees. Daar word aanbeveel dat plasmafibrinogeen as deel van 'n pasiënt se KHS-risikoprofiel gemeet moet word.

\title{
Gestratifiseerde ewekansige treilopnames van kommersiële bodemvisspesies aan die Kaapse suidkus: 1986 - 1990
}

\author{
A. Badenhorst \\ Navorsingsinstituut vir Seevisserye, Privaat sak X2, Roggebaai 8012
}

Die treilvissery vir Kaapse stokvis is die grootste vissery in die wêreld wat op stokvis gebaseer is. Ten einde die omvang van dié bron aan die suidkus te beraam en te bestuur, is bodemtreilopnames in 1986 van stapel gestuur. Die primêre doelwit was om biomassaskattings te verkry om aan te sluit by soortgelyke opnames wat aan die weskus uitgevoer word. Tegelykertyd sou inligting oor twee ander belangrike bronne, naamlik tongvis en marsbanker, ook ingewin word.

Die opnamegebied het van die kus tot 'n diepte van $500 \mathrm{~m}$ tussen Kaap Agulhas en Port Alfred gestrek. Die gebied is in vier dieptestratums, naamlik 0-50 m, 51-100 m, 101-200 m en $201-500 \mathrm{~m}$, verdeel. Elke stratum is in blokke van $5 \times 5$ seemyl verdeel. Treilstasies is ewekansig, volgens die verhouding van blokke in elke stratum, aan die onderskeie stratums toegewys.

Biomassa is as volg per stratum bepaal:

Biomassa $=$ gemiddelde digtheid per stratum $\mathrm{x}$ totale oppervlakte van stratum

vangs per treil

Digtheid $=\frac{\text { afstand getreil } \mathrm{x} \text { wydte van opening van }}{\text { die net }}$

Die vlakwaterstokvis (Merluccius capensis) is tydens elke vaart wydverspreid oor die vastelandsplat aangetref. Die lengteverspreidings van stokvis toon dat groter vis in dieper water aangetref word en die ouderdomsverspreiding toon dat die voorrekrute $(<3$ jaar oud) in vlak water $(<50 \mathrm{~m})$ versamel. Daar is 'n duidelike neiging dat ouer individue in dieper water aangetref word. Groot individue het soms so diep as $450 \mathrm{~m}$ voorgekom. Stokvis ouer as vyf jaar het die hoofkomponent van vangste dieper as $200 \mathrm{~m}$ gevorm.

Vlak waterstokvis was duidelik die dominante spesie aan die suidkus. Die hoogste skatting van biomassa was 223457 t (1990). Die gemiddelde biomassa oor die tydperk was tussen 160000 en $200000 \mathrm{t}$, waarvan die oorgrote meerderheid tussen 101 en $200 \mathrm{~m}$ gekonsentreer was.

Agulhastongvis (Austroglossus pectoralis) het 'n beperkte verspreiding in die opnamegebied. Dié spesie was hoofsaaklik tot water vlakker as $100 \mathrm{~m}$ beperk en die grootste vangste is in baaie soos Kaap St. Francis en Kaap Infanta gemaak, asook suidoos van Mosselbaai.

Die lengteverspreidings dui daarop dat tongvis nie sterk deur die diepte beinvloed word nie, alhoewel daar tog 'n neiging by groter vis was om in dieper water te hou.

Die ouderdomsverspreiding toon dat die vangste in vlakker water deur vis tussen drie en vyf jaar oud oorheers is. Ten spyte van 'n toename in die modale ouderdom met diepte was daar nogtans 'n groot mate van oorvleueling in die voorkoms van alle ouderdomsgroepe oor die hele verspreidingsgebied.

Biomassaskattings toon' $n$ dalende neiging vir die periode 1986-1989 en daarna 'n oënskynlike herstel. Die grootste skatting is jaarliks in die $51-100 \mathrm{~m}$ stratum gemaak.

Marsbanker (Trachurus trachurus capensis) is jaarliks in alle dieptestratums oor die hele opnamegebied aangetref, maar die meerderheid het tussen 50 en $200 \mathrm{~m}$ gehou.

Die lengteverspreidings toon dat daar sterk rekrutering in 1988 plaasgevind het. Alhoewel daar groot oorvleueling van lengtegroepe in alle jare was, het die kleiner individue ' $n$ duidelike voorkeur vir vlakker water openbaar.

Die biomassaskattings dui op sterk wisselinge tussen dieptestratums en ook tussen verskillende jare. Daar word afgelei dat die gemiddelde biomassa wat vir bodemtreilers in die opnamegebied beskikbaar is ongeveer 150000 t beloop.

Die biomassaskattings van vlakwaterstokvis aan die suidkus toon dat die bron wydverspreid oor die vastelandsplat voorkom en redelik stabiel is.

Dit wil voorkom asof die dalende neiging in biomassa van Agulhastongvis gestuit is en dat die bron 'n mate van herstel toon.

Alhoewel die marsbankerbron groot wisselinge ondergaan, was daar geen beduidende opwaartse of afwaartse neigings in die biomassaskattings nie en wil dit voorkom asof die bron redelik stabiel is. 


\title{
Bevolkingstatistieke van die eksotiese varswaterslak Marisa cornuarietis, moontlike beheeragent van slaktussengashere van bilharziase by 'n reeks konstante temperature
}

\author{
K.N. de Kock \\ Departement Dierkunde, Potchefstroomse Universiteit vir CHO, Potchefstroom 2520
}

Pogings om die varswaterslakke wat as tussengashere van bilharziase in Suid-Afrika optree chemies te beheer, is tot dusver met wisselende mate van sukses beloon. Uit 'n biologiese oogpunt beskou, sou die ideale beheermaatreël wees om tussengasheerslakke van ekonomiese belang deur kompetisie met 'n ekologiese homoloog te verplaas wat oor eienskappe soos 'n hoë voortplantingskoers en wye aanpasbaarheid beskik.

Die sukses wat met die varswaterslak Marisa cornuarietis, 'n indringerspesie vanaf Suid-Amerika, met die beheer van Biomphalaria glabrata (tussengasheerslak van urinêre bilharzia) in Puerto Rico behaal is, het aanleiding tot talle ondersoeke in hierdie verband gegee. Die afgelope dekade is ook indringende studies in Afrika noord van die ewenaar in hierdie verband gedoen. Die belowende resultate van genoemde ondersoeke het dit sinvol gemaak om die potensiaal van Marisa as beheeragent ook met betrekking tot die SuidAfrikaanse situasie te evalueer. Omdat Marisa inheems in die tropiese gebiede van Amerika is, is eerstens probeer om vas te stel waar dit in Suid-Afrika, betreffende temperatuur, moontlik sou kon vestig. Derhalwe is 'n ouderdomspesifieke lewenstabeleksperiment by vier konstante temperature uitgevoer.

Kohorte van 15 eksemplare elk is by $21,24,27$ en $30^{\circ} \mathrm{C}$ aangehou. Die eksperimentele opstelling het bestaan uit vier vlekvrystaalakwariums, elk toegerus met 'n logiese verwerker wat temperatuur noukeurig tot $\pm 0,1^{\circ} \mathrm{C}$ beheer het. Eierproduksie en mortaliteit is daagliks aangeteken en elke kohort is tweeweekliks geweeg.

Die massa per slak van die kohorte by 27 en $30^{\circ} \mathrm{C}$ het opvallend vinniger as by die twee laer temperature toegeneem en onderskeidelik die tweede hoogste en hoogste uiteindelike gemiddelde massa van 16,8 en $18,9 \mathrm{~g}$ per slak bereik.

Betreffende oorlewing het die kohort by $21^{\circ} \mathrm{C}$ verreweg die swakste presteer, want na 11 maande het slegs $33 \%$ teenoor 'n laagste syfer van $93 \%$ by die ander kohorte oorleef.

Met betrekking tot vermenigvuldigingskoers per tydseenheid was daar geen betekenisvolle verskil tussen die 3,1 en 3,2 wat respektiewelik deur die kohorte by 24 en $27^{\circ} \mathrm{C}$ bereik is nie. Desgelyks was daar geen betekenisvolle verskil tussen die 1,7 en 1,9 wat onderskeidelik vir die kohorte by 21 en $30^{\circ} \mathrm{C}$ bereken is nie. Betreffende vermenigvuldigingskoers per generasie het die kohorte by 24 en $27^{\circ} \mathrm{C}$ met respektiewelik 4804 en 4397 betekenisvol beter presteer as die 818 en 222 wat onderskeidelik vir 21 en $30^{\circ} \mathrm{C}$ bereken is.

Die resultate van hierdie ondersoek toon duidelik dat Marisa $k$-geselekteerd is, teenoor Bulinus africanus (urinêre bilharzia-tussengasheer) en Biomphalaria pfeifferi (ingewandsbilharzia-tussengasheer) wat beide $r$ geselekteerd is. Volgens die literatuur is $k$-geselekteerde spesies gewoonlik strawwe kompeteerders. Kompetisie vir voedsel en predasie speel in die geval van Marisa 'n belangrike rol in die beheerproses. Varswaterslakke lê by voorkeur hul eierpakkies op akwatiese plante. Marisa is 'n gulsige vreter van bykans alle soorte waterplante, gevolglik vind predasie van eierpakkies en pasuitgebroeide slakkies van ander spesies sowel toevallig as doelbewus plaas. Alles in ag genome, is dit nie vergesog om te voorspel dat die doeltreffendste beheer by temperature in die omgewing van $27{ }^{\circ} \mathrm{C}$ verwag sou kon word nie. Dit is waar die meeste voedsel verorber en die hoogste voortplantingskoers bereik is.

Die gedokumenteerde geografiese verspreiding van bilharzia-tussengasheerslakke in Suid-Afrika toon dat $B$. africanus, benewens in die warmer gebiede, ook in die kouer dele van die land versprei is. Daarbenewens kom dit by voorkeur in seisoenwater voor, toestande wat volgens die literatuur onaanvaarbaar vir Marisa is. Anders as B. africanus is $B$. pfeifferi tot warmer gebiede beperk en kom dit by voorkeur in standhoudende water voor. Dit is derhalwe die slotsom dat Marisa nie sinvol vir beheer van $B$. africanus onder natuurlike toestande in Suid-Afrika ingespan sou kon word nie. Daarenteen dui die resultate daarop dat dit tog in bepaalde gebiede en habitats met welslae teen $B$. pfeifferi aangewend sou kon word. Volgens berekeninge wat elders gedoen is, sou so 'n beheerprogram slegs een derde van die koste van 'n molluskisiedtoedieningsprogram beloop.

\section{Die biologie van verteenwoordigers van die genus Lamproglena}

C. Euler en A. Avenant-Oldewage

Departement Dierkunde, Randse Afrikaanse Universiteit, Posbus 524, Johannesburg 2000

Lamproglena is 'n kieuparasiet van visse. Die irritasie wat deur die parasiet veroorsaak word, vorm 'n sist as gevolg van die proliferasie van die kieuweefsel.

Lamproglena se liggaam word in drie dele verdeel, die 
sefalotoraks (kop), die toraks en die abdomen. Die sefalon is soms met die eerste torakssegment versmelt. Soos by alle verteenwoordigers van die Crustacea kom vyf paar aanhangsels op die sefalon van verteenwoordigers van die genus Lamproglena voor, maar sommige van hierdie aanhangsels is baie gewysig om by die organisme se parasitiese leefwyse aan te pas. Antennulae met setas is aanwesig en hierdie strukture is sensories, die antennae is ook sensories van aard en word gevolg deur die mandibels en maksillulae wat in die mondholte geïnkorporeer is. Die laaste paar sefalonaanhangsels, nl. die maksillae, is die hoofvashegtingstruktuur en bestaan uit 'n paar gewysigde hake. Die tweede vashegtingstruktuur is die maksillipede wat ook gewysig is en termineer in 'n klou met drie hake. Die toraks bestaan uit vyf segmente waarvan, in die geval van $L$. clariae Fryer, 1956, die eerste tot vierde elk een paar twee-assige pote bevat. Die vyfde segment of genitale segment besit een paar rudimentêre pote en twee dorso-laterale openinge waardeur die eierstringe uitsak. Die ovaria is in die derde en vierde segment geleë en as dic eiers ryp word, sak dit uit in 'n uniseriale eierstring.

Die abdomen bestaan uit drie verlengde segmente wat onduidelik verdeel is. Op die derde segment is die furkale rami aanwesig aan weerskante van die terminaal geleë anus.

Sewe larwaalstadiums kan onderskei word en bestaan uit 'n nauplius, metanauplius en vyf kopepodiedstadia gevolg deur'n mannetjie of wyfie. Slegs volwasse wyfies is parasities. L. claricle voed op bloed, maar sommige ander spesies voed op mukus en weefsel.

Verteenwoordigers van die genus Lamproglena kom veral in Afrika (13 spesies) en Asië (14 spesies) voor; een spesie kom in Europa voor. In die huidige studie is $L$. claricie en 'n ander onbekende Lamproglena-spesie in die Olifantsrivier in die Nasionale Krugerwildtuin gevind.

\title{
Die morfologie van die manlike geslagstelsel van Chonopeltis victori Avenant, Oldewage, 1991 (Crustacea: Branchiura)
}

\author{
M.J. Grundlingh en J.H. Swanepoel \\ Departement Dierkunde, Randse Afrikaanse Universiteit, Posbus 524, Johannesburg 2000
}

Die doel, aard en omvang van hierdie studie is grotendeels bepaal deur die huidige gebrek aan kennis ten opsigte van die geslagstelsels van Chonopeltis. Resultate verkry uit hierdie morfologiese studie sal gebruik word om 'n volledige en betroubare morfologiese beskrywing van die manlike geslagstelsel van die spesie daar te stel.

Parasitiese Crustacea word taksonomies in drie groepe onderskei, nl. die Branchiura, Copepoda en Isopoda. Verteenwoordigers van die Branchiura is almal visektoparasiete, met die uitsondering van enkele spesies wat ook amfibieë as gashere kan benut. Morfologiese aanpassings vir hul akwatiese ektoparasitiese leefwyse sluit o.a. in 'n dorsoventraal afgeplatte liggaam; 'n breë skildvormige karapaks met vergrote respiratoriese areas; twee saamgestelde oë asook 'n enkele osellus; twee paar maksillas waarvan die eerste paar omvorm is tot kragtige hake of suiers vir vashegting; vier paar torakale swempote en 'n kort, ongesegmenteerde abdomen. Die parasietliggaam besit ook verskeie getande skubbe, stekers en setas waardeur behoud van posisie op die gasheer vergemaklik word. Die geslagte is geskei, met die wyfies gewoonlik groter as die mannetjies.

Die klas Branchiura word huidig deur ongeveer 150 spesies van vier genera, nl. Argulus Müller, 1785; Dolops Andouin, 1837; Chonopeltis Thiele, 1900 en Dipteropeltis Calman, 1912, verteenwoordig. Chonopeltis is egter die enigste van hierdie vier genera wat endemies aan Afrika is, en word huidig deur slegs 12 spesies verteenwoordig waarvan Chonopeltis victori Avenant-Oldewage, 1991 die onlangste beskryf is.

Alhoewel daar in enkele gevalle ook van skandeerelektronmikroskopie gebruik gemaak is, is die meeste morfologiese beskrywings van hierdie spesies uitsluitlik aan die hand van ligmikroskopiese bestudering van totaalpreparate gedoen - sonder enige morfologiese beskrywing van die geslagstelsels. Gevolglik is daar huidig min bekend aangaande die morfologie van die manlike sowel as vroulike geslagstelsels - nie alleen van die spesies van Chonopeltis nie, maar ook van die ander drie genera van die Branchiura.

Tydens opnames van varswatervisparasiete van die Olifantsrivier in die Nasionale Krugerwildtuin gedurende 1990 en 1991 deur die Navorsingseenheid van Varswateren Terrestriële Ekologie aan die RAU, is verskeie eksemplare van 'n nuwe Chonopeltis-spesie op die liggaamsoppervlak en vinne van vier visspesies, nl. Barbus marequensis, Labeo rosae, L. rubrupunctatus en $L$. ruddi gevind. Hierdie parasiete, beskryf as Chonopeltis victori Avenant-Oldewage, 1991 , is lewend vanaf die visgashere verwyder en onmiddellik in monsterbotteltjies, gevul met gefiltreerde rivierwater geplaas. Daarna is die parasiete plat in verhitte $10 \%$-GNF (gebufferde neutrale formalien) of $70 \%$-etanol gefikseer. Materiaal vir histologiese bestudering is in $10 \%$ GNF gepreserveer en vir skandeerelektronmikroskopie in $70 \%$-etanol. Vir die bestudering van totaalpreparate is eksemplare in $90 \%$-laktofenol opgehelder en gemonteer. Tekeninge is met behulp van 'n tekenbuis, gemonteer op 'n Zeiss-standaard 18 mikroskoop gedoen.

GNF-gepreserveerde materiaal is in paraffienwas asook metielakrilaathars ingebed, waarna semidun histologiese seriesneë gemaak is wat onderskeidelik met AsokarmynAzaan en Hematoksilien-Eosien gekleur is. Deur grafiese rekonstruksies van semidun seriesneë te maak, is meer volledige en gedetailleerde morfologiese inligting van die manlike geslagstelsel verkry.

Volgens die resultate uit hierdie morfologiese studie van Chonopeltis victori verkry, bestaan die manlike geslagstelsel uit gepaarde testes geleë in die abdomenlobbe, twee kort 
vasa efferentia wat elk vanaf die proksimale kant van 'n testis na vore loop en in die agterkant van die toraks verenig om 'n spermreservoir, die vesikula seminalis, te vorm. Laasgenoemde vertak verder na vore in die toraks in twee dunner, asimmetries gekronkelde vasa deferentia wat terugvou en verder na agter vernou om die twee ejakulatoriese buise te vorm wat in die genitalatrium open. Die genitaalatrium open ventraal aan die agterkant van die vierde torakaalsegment in die genitaalopening. Geassosieerd met die manlike geslagstelsels kom twee blindeindigende buise in die toraks voor wat tesame met die ejakulatoriese buise in die genitaalatrium open.

\title{
Die effek van akarbose op die stollingsfaktore van die Zuckervetrot
}

\author{
J.C. Jerling \\ Departement Fisiologie, Potchefstroomse Universiteit vir $\mathrm{CHO}$, Potchefstroom 2520 \\ H.H. Vorster en C.S. Venter \\ Departement Dieetkunde, Potchefstroomse Universiteit vir CHO, Potchefstroom 2520 \\ D.G. van der Nest \\ Proefdiersentrum, Potchefstroomse Universiteit vir CHO, Potchefstrom 2520
}

\begin{abstract}
Akarbose (Bay g 5421), 'n bakteriële alfa-glukosidaseinhibeerder, veroorsaak wanvertering en vertraagde absorpsie van koolhidrate, wat lei tot 'n dosisafhanklike verlaging in postprandiale glukose- en insulienvlakke in gesonde en diabetiese proefpersone. Akarbose lei ook tot verlaagde serumtrigliseriedvlakke en verhoogde insuliensensitiwiteit in diabetiese proefpersone en in sekere diermodelle.

In hierdie studie het ons die moontlikheid ondersoek dat verbeterde metaboliese beheer met akarbose in die insulienweerstandbiedende Zuckervetrot gepaardgaan met veranderinge in plasmafibrinogeen- en faktor VII-vlakke. Plasmafibrinogeen en faktor $\mathrm{VII}_{e}$ is bekende risikofaktore vir koronêre hartvaatsiekte (KHS) en is verhoog in die Zuckervetrot.

Twintig Zuckervetrotte tussen 500 en $642 \mathrm{~g}$ is ewekansig in 'n eksperimentele groep en 'n kontrolegroep verdeel, met vyf mannetjies en vyf wyfies in elke groep. Beide groepe het 'n semisintetiese Westerse dieet gevolg waarin vet $37 \%$, proteïene $28 \%$ en koolhidrate $35 \%$ tot die totale energiewaarde bygedra het. Die eksperimentele groep het $100 \mathrm{mg}$ akarbose $/ 250 \mathrm{~g}$ droë kos as 'n dieetbyvoeging gekry. Na 6 weke op dié dieet is bloedmonsters vir die bereiding van serum en sitraatplasma uit genarkotiseerde rotte $(6 \% \mathrm{~m} / \mathrm{v}$
\end{abstract}

natriumpentobarbital) deur kardiale punksie verkry. Serumglukose, -insulien, -lipiede en -proteiene en plasmastollingsfaktore is met ensimatiese, kolorimetriese en stollingsmetodes gemeet. 'n Variansie-analise en Student-NewmanKeulstoetse is met behulp van die SAS-rekenaarprogram gedoen.

Die gemiddelde liggaamsınassatoename van $17,1 \mathrm{~g}$ in die eksperimentele groep en $72.4 \mathrm{~g}$ in die kontrolegroep gedurende die eksperimentele periode was hoogs betekenisvol ( $p<0,001$ ). Seruminsulien, -trigliseriede, totale cholesterol, -albumien en plasmafaktor VII -aktiwiteit is ook betekenisvol ( $\mathrm{p}<0,05)$ deur akarbosesupplementering verlaag. Verlagings in serumglukose, plasmafibrinogeen en -faktor $\mathrm{V}_{\mathrm{c}}$ aktiwiteit was nie betekenisvol nie.

Die verbetering van lipiedmetabolisme as gevolg van akarbosesupplementering (waarkynlik as gevolg van verbeterde insuliensensitiwiteit) is moontlik verantwoordelik vir die laer faktor $\mathrm{VII}_{\mathrm{c}}$-aktiwiteit. Die verlaging in serumalbumienvlakke is 'n moontlike nadelige effek van akarbose en daar behoort verder ondersoek daarna ingestel te word. Dit is dus moontlik dat akarbose die risiko vir KHS in diabetes mellitus-pasiënte mag verlaag deur die effek wat dit op die lipiedmetabolisme en die stollingsisteem het.

\section{Die raaiselagtige beweging van oösiete deur die oviduk van sommige aalwurms (nematoda)}

\author{
J.C. de W. Kruger \\ Departement Dierkunde, Randse Afrikaanse Universiteit, Posbus 524, Johannesburg 2000
}

Die oviduk van plantparasitiese nematode is 'n duidelik afgebakende gedeelte van die vroulike geslagstelsel, wat ryp oösiete vanaf die ovarium na die uterus vervoer. Die oviduk verbreed opvallend waar dit by die uterus aansluit, en volwasse eierselle word normaalweg, net voor bevrugting, in hierdie sakagtige struktuur (die sogenaamde pars dilatata 
oviductus of spermateka) aangetref. Interessant genoeg word gamete egter selde in die smaller, proksimale gedeelte van die oviduk waargeneem, wat waarskynlik daarop dui dat die oösiete relatief vinnig deur hierdie gedeelte moet beweeg.

'n Voorlopige ligmikroskopiese studie van vars, sowel as gefikseerde en gemonteerde vroulike geslagstelsels van verskeie spesies van die genus Xiphinema van Suid-Afrika, het aangetoon dat die smal, buisvormige oviduk opgebou is uit 25 tot 35 skyfvormige, enkelkernige. effens bikonkawe selle wat in 'n enkel ry dig teen mekaar gerangskik is, en omring is van 'n dun, deurskynende membraan. Dit was veral die "vlekking" van die materiaal met orsienpropioonsuur en geringe osmotiese versteurings wat die ovidukselle op so 'n wyse uitmekaar laat skuit het dat hulle algemene mortologie en spesifieke oriëntasie ten opsigte van mekaar, beter gevisualiseer en geïnterpreteer kon word.

Aangesien 'n duidelike lumen nooit in enige van die ovidukselle waargeneem is nie, is die fisiese beweging van oosiete deur die smal gedeelte van die oviduk ligmikroskopies ondersoek. Ligte drukking is toegepas op vars voortplantingsmateriaal wat tydelik op 'n voorwerpglasie in 'n fisiologiese soutoplossing gemonteer is. As gevolg van die drukking vervorm die ovaalvormige oösiet tot 'n lang, vernoude struktuur wat vanaf die ovarium, deur die smal gedeelte van die oviduk tot in die sakagtige spermateka vloei, waar dit dan weer terugkeer na die oorspronklike vorm.

Hierdie studie het aangetoon dat beweging van oossiete deur die proksimale deel van die oviduk 'n realiteit is. Tockomstige Transmissie-elektronmikroskopiese (TEM) en Skandeerelektronmikroskopiese (SEM) studies behoort lig te werp op die oënskynlike raaisel van geslagselbeweging deur 'n buisvormige struktuur sonder 'n opvallende lumen.

\title{
Die filogenetiese implikasie van 'n koronoiëdbeen by die Dinocephalia (Therapsida: Amniota)
}

\author{
J.A. van den Heever \\ Departement Soölogie, Universiteit van Stellenbosch, Stellenbosch 7600
}

\author{
F.E. Grine \\ Department of Anthropology, State University of New York, Stony Brook, New York, USA
}

As voorvaders van die hedendaagse soogdiere is die soogdieragtige reptiele van kritieke belang in die ontrafeling van die filogenetiese ontstaan van soogdiere uit reptiele. Verwantskappe binne hierdie takson is dus van ewe groot belang. Tans bestaan daar onduidelikheid oor die teenwoordigheid van 'n koronoiëdbeen in die onderkaak van die Dinocephalia. Verskeie werkers het hierdie probleem al nagevors. Orlov (1958) kon nie die been in eksemplare van die primitiewe Russiese Dinocephalia opspoor nie. Dit het aanleiding gegee tot die gedagterigting dat die been heeltemal afwesig is by die Dinocephalia. Romer (1966) het die Dinocephalia en die Dicynodontia, waar die been werklik afwesig is, saam gegroepeer op grond van hierdie eienskap. Volgens Boonstra (1962) en Hopson en Barghusen (1986) is die been wel teenwoordig. King (1988) is van mening dat die been afwesig is. Saam met addisionele kenmerke groepeer sy gevolglik die Dinocephalia en die Dicynodontia as sustergroepe binne die Anomodontia op grond van die volgende vier kenmerke: 1. Koronoiedbeen afwesig. 2. Neusgate nieterminaal geleë op snoet en premaksilla met lang uitsteeksel aan agterkant. 3. Interne trochanter van die femur gereduseer of afwesig. 4. Vomer ventraal gegroef. Hierdie siening kom filogeneties verdag voor en daarom is dit belangrik om finaal uitsluitsel te verkry oor die aanwesigheid van veral 'n koronoïedbeen by die Dinocephalia, al dan nie.

Ons analise van die fossielmateriaal van die SuidAfrikaanse Museum in Kaapstad, tans die grootste versameling Dinocephalia ter wêreld, asook eksemplare in die versameling van die American Museum of Natural History, bewys dat 'n koronoied ongetwyfeld aanwesig is by die Suid-Afrikaanse Dinocephalia. Na uitgebreide mikroskopiese preparering van die fossielmateriaal is dit duidelik dat die been sydelings afgeplat en van voor na agter verleng is. Dit is dorsomediaal op die onderkaak, feitlik teen die basisse van die kiestandkrone geleë en strek in verskeie eksemplare as 'n dun, plat been oor feitlik die hele lengte van die kiestandry. Een eksemplaar van die American Museum of Natural History, waar die voorste gedeelte van die koronoïed beskadig is, het na preparasie getoon dat daar' $n$ vlak holte in die kaak bestaan waarin die been geleë is. Verdere analise van die onderkaak met behulp van rekenaartomografie het die bestaan van die koronoiedbeen en die holte waarin dit gelee is, onteenseglik bevestig.

Volgens Hopson en Barghusen ( 1986) bestaan daar twyfel or die korrektheid van die naatpatrone van die onderkake van Syodon en Titanophoneus in die illustrasies van Orlov (1958). Onlangse data van Hopson (persoonlike kommunikasie) aangaande die Russiese Dinocephalia dui daarop dat 'n koronoied aanwesig is by Titanophoneus en Doliosauriscus en dat by eksemplare soos Syodon, waar die koronoied nie sigbaar is nie, daar wel ' $n$ holte aanwesig is waar die been geleë was. Die implikasie is dus dat alle lede van die Dinocephalia 'n koronoïed besit het en dat die groepering van hierdie takson saam met die Dicynodontia as die Anomodontia op grond van die afwesigheid van die koronoied, verkeerd is.

Ons interpretasie van die posisie van die uitwendige neusopening toon dat dit nie 'n diagnostiese kenmerk is nie. By die Theriodontia is die neusopeninge wel terminaal geleë aangesien die voorrand van die skedel vertikaal strek. By die Dinocephalia strek die snoetpunt nie vertikaal nie, maar skuins, sodat die krone van die groot snytande baie prominent na voor uitsteek. By sowel die Theriodontia as die Dinocephalia is die wortels van die snytande ongeveer net so lank 
soos die krone. Dit is dus duidelik dat die gedeelte van die premaksilla tussen die kaakrand en die uitwendige neusopening deur die alveoli van die snytande in beslag geneem word. Die afstand tussen die uitwendige neusopening en die kaakrand word dus bepaal deur die lengte van die wortels van die snytande. Omdat die snoet van die Dinocephalia nie vertikaal nie maar skuins na vore strek, lyk dit of die uitwendige neusopeninge meer na agter geleë is. By die Dicynodontia is die uitwendige neusopeninge ook verder na agter geleë terwyl daar nie snytande aanwesig is nie. Die rede hiervoor is voor die hand liggend, aangesien hierdie diere horingskedes, netsoos hedendaagse skilpaaie, aan sowel die bo-as die onderkaak gedra het. As gevolg van die dorsale strekking van die borand van die horingskede is die neusopeninge meer na agter geleë. Die posisie van die uitwendige neusopeninge by die Dinocephalia en die Dicynodontia is dus die resultaat van verskillende funksionele aanpassings en nie onderlinge verwantskap nie.

Volgens King (1988) is die interne trochanter by die Russiese Dinocephalia en die Suid-Afrikaanse vorm Moschops, nie duidelik ontwikkel nie. In teenstelling hiermee rapporteer Boonstra (1955) dat die interne trochanter duidelik te sien is. Ons analise van hierdie materiaal het getoon dat die interne trochanter wel goed ontwikkel is by verskillende Suid-Afrikaanse Dinocephalia o.a. Moschops en Tapinocephalus. Volgens Hopson (persoonlike kommunikasie) is die interne trochanter by die Russiese Dinocephalia wel goed ontwikkel.

King (1988) is van mening dat die Dinocephalia en die Dicynodontia beide ' $n$ lengteverlopende groef aan die ventrale oppervlak van die vomer besit en dat hierdie kenmerk slegs by genoemde groepe voorkom. In teenstelling met haar opvatting is dieselfde struktuur reeds gerapporteer by ander lede van die Therapsida en wel die Ictidorhinidae deur Sigogneau (1970) en Mendrez-Carroll (1975).

$\mathrm{Na}$ ons mening is dit dus prematuur om die moontlike verwantskap tussen die Dinocephalia en die Dicynodontia te vergestalt op grond van bogenoemde vier kenmerke. Dat daar wel 'n verwantskap tussen hierdie twee groepe mag bestaan, is hoegenaamd nie uitgesluit nie. Dit kan egter nie op bogenoemde vier kenmerke gebaseer wees nie.

\title{
Relatiewe volopheid en verspreiding van muskiete in die Bloemfonteinse voorstedelike gebied
}

\author{
R. van Staden \\ Departement Virologie, Universiteit van die Oranje-Vrystaat, Posbus 339, Bloemfontein 9300
}

T.C. de K. van der Linde

Departement Entomologie, UOVS, Bloemfontein 9300

Studies wat in die Bloemfontein-distrik op Culicidae gedoen is, het getoon dat Culex theileri, $C x$. univittatus, Aedesjuppi en Ae. caballus die algemeenste voorkom en as vektore of potensiële vektore van Slenkdalkoors-, Sindbis-, Wes-Nylen Wesselsbronvirus kan optree. Hoë reënval lei tot skerp stygings in die Culicidae-getalle, wat op hulle beurt tot verhoogde voorkoms van bogenoemde siektes kan lei. Met bogenoemde in gedagte, is besluit om die verskeidenheid en relatiewe volopheid van die verskillende muskietspesies in die Bloemfonteinse voorstedelike gebied te ondersoek.

Muskiete is vanaf Januarie 1989 tot Desember 1990 versamel. New Jersey-ligvalle is weekliks by die onderskeie versamelpunte uitgeplaas. Omdat die verspreiding en volopheid van muskiete direk afhanklik is van die weerstoestande is die inligting vanaf die weerkantoor by J.B.M. Hertzoglughawe verkry.
Tydens die opnameperiode is tien spesies versamel. Daar is 'n duidelike opbloei van Aedes-spesies na hoë reënval gedurende die somermaande. Die afname in voorkoms gedurende die kouer herfsmaande, ten spyte van hoë reënval, is moontlik as gevolg van die minimum temperatuur wat as beperkende omgewingsfaktor uitbroeiing verhoed. Anopehles-spesies is hoofsaaklik gedurende die koeler maande versamel. Culiseta longiareolata is die enigste Culiseta-spesie wat versamel is. Vier Culex-spesies is versamel. $C x$. theileri is die dominante spesie. Dit is die enigste spesie wat feitlik regdeur die jaar versamel is.

Gedurende die studie is die meeste volwasse muskiete in die westelike deel van die stad versamel. Dit kan toegeskryf word aan die heersende windrigting wat noordwes is. Temperatuur en reënval was die belangrikste faktore wat die getalle van volwasse muskiete beinvloed het. 


\title{
Die voortplantingsbiologie van die ouvolk Cordylus giganteus (Reptilia; Cordylidae)
}

\author{
J.H. van Wyk \\ Departement Soölogie, Universiteit van Stellenbosch, Stellenbosch 7600)
}

Cordylus giganteus (sonkyker/ouvolk) is die grootste van die gordelakkedisse (Cordylidae) en endemies tot die Hoëveldse graslandstreke van Suid-Afrika. Hierdie akkedisse bly in ondergrondse tonnels wat hulle self grawe en leef hoofsaaklik van grondlewende kewers (Coleoptera). Die voortgesette vernietiging van die ouvolk se natuurlike habitat deur landbou, mynbou en stedelike ontwikkeling maak die inwin van inligting rakende die voortplantingsbiologie en algemene ekologie 'n voorvereiste vir die doeltreffende bewaring en hervestiging van hierdie bedreigde spesies.

Akkedisse is maandeliks versamel in 'n gebied digby Harrismith waar nuwe dorpsontwikkeling in die vooruitsig gestel is. Die dicre is verkoel en na 'n laboratorium in Bloemfontein vervoer. Bloed- en weefselmonsters is gedurende 'n nadoodse ondersoek geneem. Deur die bestudering van histologiese sneë van die manlike en vroulike geslagsorgane is die voortplantingsaktiwiteit bepaal. Hormoonvlakke (testosteroon, estrogeen en progesteroon) in die plasma is bepaal deur middel van direkte radio-immunoessaiëring (RIA) (Diagnostic Products).

Jong wyfies raak geslagsryp in hul vyfde lewensjaar (snoet-kloakalengte $(\mathrm{SKL})= \pm 168 \mathrm{~mm})$. Alhoewel embrionale ont wikkeling volledig in die uterus plaasvind (viviparevoortplantingswyse), is die ovum dooieragtig. Dooierneerlegging begin in die herfs voordat die akkedisse in hul ondergrondse skuilings oorwinter. Ovulasie vind in Oktober plaas, kort nadat die akkedisse weer buite te sien is. Paring vind in hierdie tyd plaas en swangerskap duur tot Januarie of Februarie wanneer geboorte geskenk word aan 2 - 4 kleintjies. Embrionale groei, veral in die laaste trimester, dui daarop dat 'n funksionele chorio-allantoïese plasenta vorm.

Estrogeenvlakke in die plasma neem geleidelik toe tydens dooierneerlegging en bereik 'n hoogtepunt net voor ovulasie. Progesteroonvlakke neem toe na ovulasie en bereik 'n hoogtepunt gedurende die tweede trimester van embrionale ontwikkeling. Na geboorte degenereer die corpora lutea en daal progesteroonvlakke in die plasma dramaties.

Alle volwasse wyfies begin nie onmiddellik weer met 'n volgende siklus nie, maar kan tot so lank as twee jaar reproduktief onaktief wees. Die hipotese word gehandhataf dat slegs wyfies wat genoeg energiereserwes na parturisie het, onmiddellik met 'n dataropvolgende dooierneerleggingsiklus sal voortgaan. Hierdie verskynsel gee daartoe aanleiding dat hoogstens die helfte $(50 \%)$ van die volwasse wyfies in 'n bevolking, nakomelinge in enige jaar sal lewer.

Ouvolk-mannetjies word geslagsryp in die vyfde lewensjaar (SKL $= \pm 165 \mathrm{~mm}$ ). In teenstelling met die wyfies, waar ovogenese 'n tweejaarlikse verskynsel kan wees, is spermatogenese 'n jaarlikse verskynsel in alle volwasse mannetjies in die bevolking. Spermatogenetiese aktiwiteit begin in die somer en spermiogenese is in volle swang teen die herfs. In die laatherfs, net voor hibernering, staak alle spermatogenetiese aktiwiteite en vind regressie van die testis plaas. Spermatozoa word egter gestoor in die epididimis en vas deferens tot in die lente wanneer ovulasie in die wyfies plaasvind.

Testosteroonvlakke in die plasma styg geleidelik gedurende spermatogenese en bereik 'n hoogtepunt in die herfs tydens spermiogenese. Tydens testikulêre regressie daal testosteroonvlakke in die plasma dramaties om 'n laagtepunt gedurende die wintermaande te bereik. 'n Tweede styging in testosteroonvlakke is gedurende die lente in die plasma gemeet. Hierdie styging in plasmatestosteroonvlakke is van korte duur en nie geassosieerd met spermiogenetiese aktiwiteit nie, behalwe dat dit net voor die begin van 'n nuwe spermatogenesesiklus voorkom. Terselfdertyd mag die hö̈ testosteroonvlakke geassosieer word met paringsgedrag in die lente.

Uit die resultate is dit duidelik dat die jaarlikse voortplantingsiklusse van mannetjies en wyfies nie goed gesinkroniseerd is nie. Indien voortplanting onder ekstrensieke beheer staan, kan aanvaar word dat die geslagte verskillend op dieselfde omgewingsfaktore reageer of deur verskillende faktore beheer word. Alternatiewelik beskou, kan die onderskeie siklusse reeds grootliks endogeen van aard wees en 'n produk wees van hierdie spesies se evolusionêre verlede.

\section{Karakterisering van die bobbejaan (Papio ursinus) as model vir androïede oormassa}

\author{
C.S. Venter, H.H. Vorster, T.S.P. van der Walt, J.H. de Ridder en D.G. van der Walt \\ Departemente Dieetkunde, Menslike Bewegingskunde en Proefdiersentrum, PUCHO, Potchefstroom 2520
}

C.M. Smuts

Navorsingsinstituut vir Voedingsiektes, MNR, Tygerberg 7505

Oormassa is 'n bekende, beheerbare risikof aktor vir koronêre hartvaatsiekte. Dit het onlangs duidelik geword dat androiede (sentrale) obesiteit beter met sterftesyfers korreleer as ginoiede obesiteit. Hipertensie, hiperfibrinogenemie, 
hiperinsulinemie, hipertrigliseridemie en verlaagde serumvlakke van hoëdigtheidslipoproteïencholesterol kom dikwels in androied vetsugtige persone voor. Geskikte dierlike modelle om die invloed van androïede obesiteit op metaboliese prosesse te bestudeer, ontbreek.

In hierdie studie is die effek van gekontroleerde massaverlies op plasmafibrinogeen-, seruminsulien- en -lipoproteïenvlakke bepaal. Twaalf manlike bobbejane (Papio ursinus), in individuele hokke gehuisves, se basiese dieet is vir 6 maande lank met sjokolade ( $75 \mathrm{~g} / \mathrm{dag}$ ) en brosbrood (40) g/dag) gesupplementeer. Die totale energie-inname was $9100 \mathrm{~kJ}$ per bobbejaan per dag. Antropometriese afmetings en veneuse bloedmonsters is van genarkotiseerde bobbejane (25-30 mg natriumpentobarbital/kg) geneem na 'n 12-uurvasperiode. Serum, sitraatplasma (1:9v/v)en EDTA-plasma is berei vir die bepaling van glukose (glukose-oksidasiemetode), immunoreaktiewe insulien (dubbelteenliggaam ensiem-immunologiese toetsstel, Boehringer Mannheim), lipiede en lipoproteiene (ensimaties nefelometries) en plas- mafibrinogeen (gewysigde Claussmetode, Behringwerke). Insuliensensitiwiteit is bereken as die omgekeerde produk vandie vastende insulien- en glukosevlakke, vermenigvuldig met 10000 . Vervolgens is die bobbejane vir 7 weke lank die basiese dieet gevoer $(6.580 \mathrm{~kJ}$ perdag) en dieselfde parameters is weer gemeet.

Tydens die periode van energiebeperking het die gemiddelde liggaamsmassa van $13,30 \mathrm{~kg}$ na $11,95 \mathrm{~kg}$ verlaag, en liggaamsdigtheid betekenisvol verhoog $(p<0.001)$. Die abdominale en nekomtrek en die subumbilikus- en subskapulavelvoudikte het betekenisvol afgeneem.

Massaverlies het gepaard gegaan met statisties betekenisvolle verlagings in konsentrasie totale serumcholesterol, -trigliseriede, -insulien en plasmafibrinogeen $(p<0,05)$. Die verhouding van hoëdigtheidslipoproteiencholesterol tot totale serumcholesterol het betekenisvol toegeneem en insuliensensitiwiteit het verbeter. Die bobbejaan (Papio ursinus) is dus 'n geskikte model vir die bestudering van die metaboliese gevolge van androiede oormassa.

\title{
Liggaamsoriëntasie van die swartwildebees in 'n semi-ariede omgewing
}

\author{
S. Vrahimis en O.B. Kok \\ Departement Dierkunde, Universiteit van die Oranje-Vrystaat, Posbus 339, Bloemfontein 9300
}

Die swartwildebees Connochaetes gnou is tot ope grasveld van die sentrale plato van Suid-Afrika beperk. Hoewel verspreide bome in die konsentrasiegebiede van wildebeeste mag voorkom, maak die diere selde indien ooit van bome vir skadu of skuiling gebruik. Oor die algemeen is hierdie donker gekleurde boksoort dus aan direkte sonstraling en ander, dikwels uiterste, klimaatstoestande blootgestel. Ten einde te bepaal of die liggaamstermoregulering van swartwildebeeste deur spesifieke gedragspatrone beinvloed word at dan nie, is die liggaamsoriëntasie van die bokke met betrekking tot sonshoek en windrigting ondersoek.

Alle veldwerk is in die Soetdoring Natuurreservaat, ongeveer $35 \mathrm{~km}$ noordwes van Bloemfontein, uitgevoer. Die gebied is op die grens tussen die Skyn Hoër Karoo- en droë Cymbopogon-Themeda-veldtipes geleë. Koue, droë winters met 'n gemiddelde daaglikse minimum temperatuur van $-1,5$ ${ }^{\circ} \mathrm{C}$ in Junie en warm, sonnige somers met 'n gemiddelde daaglikse maksimum temperatuur van $30,5^{\circ} \mathrm{C}$ in Januarie word normaalweg in die streek ondervind. Die gemiddelde jaarlikse reënval beloop $450 \mathrm{~mm}$, terwyl nagenoeg 120 rypdae per jaar gedurende Mei - September voorkom.

Altesaam 2304 waarnemings van die liggaamsoriëntasie van swartwildebeeste is oor ' $n$ tydperk van 25 afsonderlike ure gedurende die midwinter ( 24 Junie 1985 ) en midsomer (27 Januarie 1986) gemaak. Die onderstaande besonderhede is op 'n kwartierlikse basis van sonop tot sononder tydens elke opname aangeteken:

1. Hoek tussen die oorlangse oriëntering van die bok en die magnetiese noorde $\left(0^{\circ}\right)$ deur een van agt vektore $\left(0-45^{\circ}\right.$, $45-90^{\circ}$, deur tot $360^{\circ}$ ) aan elke individu toe te ken.
2. Windrigting, deur dieselfde vektore te gebruik, en windspoed met behulp van 'n handgedraagte bakkieanemometer.

3. Ongeskermde temperatuur met behulp van 'n swartboltermometer om die donker pelskleur van die swartwildebees na te boots.

4. Wildebeeste bewegend of rustend.

Bepalings van die resultante hoek van oriëntasie is gebaseer op die formule van Zar (1984), terwyl die sonshoogte en -asimut vir elke uur van waarneming bereken is deur van 'n eenvoudige rekenaarkode en sterrekundige almanak gebruik te maak.

Swartwildebeeste het op 'n soortgelyke wyse ten opsigte van direkte sonstraling en wind tydens die opnameperiodes in verskillende seisoene gereageer. Gedurende die vroeë oggend en laat middag wanneer die sonshoogte en omgewingstemperatuur relatief laag is, oriënteer die bokke klaarblyklik breedsy ten opsigte van die son. Deur die grootste oppervlakte van die liggaam dus aan inkomende sonstrale bloot te stel, word hitte-opname grootliks vergemaklik. Namate die omgewingstemperatuur gedurende die middel van die dag toeneem, toon die bokke egter 'n besliste neiging om hul lengte-as in lyn met die son te oriënteer. Sodoende word die kleinste oppervlakte van die liggaam aan direkte sonstrale blootgestel waardeur oormatige hittelading tot 'n groot mate voorkom kan word.

Oriëntasie ten opsigte van die sonshoek behoort egter versigtig geinterpreteer te word. Gedurende Desembermaand bereik die son in die studiegebied 'n hoogte van ongeveer $83^{\circ}$. Dit beteken dat weinig rigtinggewende inligting op die 
horisontale vlak gedurende die middel van die dag deur die son verskaf word. Op die hitte van die dag behoort liggaamsoriëntasie dus min verband met die oorhoof se posisie van die son te toon. In hierdie opsig speel wind waarskynlik 'n belangrike rol by termoregulering. Dit blyk veral uit die oorwegend parallelle posisie ten opsigte van die windrigting wat gedurende die Januarie-opname gehandhaaf is. Deur die grootste hoeveelheid lugstroming oor die hele lengte van die liggaam te verseker, kan effektiewe afkoeling teweeggebring word.

Die feit dat die meeste diere 'n voorkeur getoon het om gedurende die hitte van die dag te lê eerder as om te staan, is miskien veelseggend. Sulke gedrag sou waarskynlik daartoe lei dat die opname van gereflekteerde radiasie vanaf die grond effektief verminder kan word. Dit wil dus voorkom asof 'n kombinasie van faktore eerder as 'n enkele aspek die liggaamsoriëntasie van swartwildebeeste in 'n semi-ariede omgewing beïnvloed.

\title{
Faktore betrokke by die bepaling van schistosoomparasiet- tussengasheerverenigbaarheid
}

\author{
C.T. Wolmarans en S.W. Nieuwoudt \\ Departement Dierkunde, Potchefstroomse Universiteit vir CHO, Potchefstroom 2520
}

Die verskynsel dat sekere organismes in staat is om ander organismes te infekteer en hulle as gashere aanwend om hulle eie voortbestaan te verseker, is algemeen in die natuur. Dit beteken egter dat die invallende organisme onder andere in staat moet wees om homself teen die verdedigingsmeganismes waaroor die gasheer beskik, te beskerm. Hierdie aspek is by die schistosoomparasiet Schistosoma haematobium, wat die varswaterslak Bulinus africanus parasiteer, ondersoek. Twee van die algemeenste meganismes van immuunontduiking, nl. molekulêre mimikrie (parasiet vervaardig gasheeragtige proteiene) en antigeenverkryging (parasiet leen gasheerproteiene) is van nader bekyk.

Mirasidiums van $S$. haematobium is uit Saccostomus campestris-muise geisoleer en in vitro na die intraslakparasietstadium nl. sporosiste, getransformeer. Die teenwoordigheid van slakagtige antigene op die oppervlakintegument van die sporosiste is met behulp van ' $n$ indirekte fluoresserende antiliggaamtegniek nagegaan. Hiervoor is die sporosiste opeenvolgend in konyn-antislak-antiliggame en fluoresserende bok-antikonyn-antiliggame geïkubeer en met behulp van 'n Leitz Orthoplan-fluoressensiemikroskoop ondersoek. Kontrole-eksperimente om die moontlikheid van niespesifieke fluoressensie na te gaan, is uitgevoer.

Om te bepaal of die parasiet van antigeenverkryging as meganisme vir immuunontduiking gebruik maak, is lewende sporosiste in hemoglobienvrye slakhemolimf geïnubeer. Die sporosiste en slakhemolimf is hierna afsonderlik versamel en vir poli-akrielamiedjelelektroforese voorberei. Kontrolemonsters wat bestaan het uit vars getransformeerde sporosiste en slakhemolimf waarin geen inkubering plaasgevind het nie, is ook geëlektroforeer. Na elektroforese is die jel met silwer gekleur en is die proteienprofiele met ' $n$ densitometer grafies voorgestel.

Hierdie ondersoek het getoon dat die antiliggame wat teen heel slakke in konyne opgewek is aan die oppervlakintegument van die sporosiste gebind het. Die feit dat die sporosiste in 'n slakmateriaalvrye in vitro-medium getransformeer is, bevestig dat die slakagtige antigene op die sporosistoppervlak deur die sporosiste vervaardig word. Bewyse uit die literatuur dat antiliggame teen 'n spesifieke slakspesie aan sowel 'n verenigbare as 'n onverenigbare parasietspesie bind, waarsku teen die afleiding dat molekulêre mimikrie soos in die huidige studie gevind, sonder meer as 'n immuunontduikingsmeganisme beskou kan word. Die feit dat sporosiste slakagtige antigene vir tot 48 uur na transformering vertoon en die slak se immuunaanval tydens die periode die hewigste is, maak 'n afleiding dat molekulêre mimikrie wel by beskerming betrokke kan wees, egter relevant. Dit moet verder in gedagte gehou word dat die indirekte fluoresserende antiliggaamtegniek, wanneer van poliklonale antiliggame gebruik gemaak word, nie sensitief genoeg is om op die molekulêre vlak te toon dat binding aan onverenigbare en verenigbare parasiete mag verskil nie. Dit lei daartoe dat die bestaan van unieke slakagtige reseptore by die verenigbare parasiet wat by beskerming betrokke mag wees, nie geidentifiseer word nie. Toekomstige navorsing sal hopelik die bestaan al dan nie van sodanige reseptore bevestig.

Wat die moontlikheid betref dat die sporosiste antigene van die slak leen om hulleself onherkenbaar te maak, is die volgende gevind: Densitometeranalises van die geinkubeerde sporosiste het indien dit met die kontrolesporosiste vergelyk word 'n ekstra proteienband van tussen 16 en $24 \mathrm{kd}$ vertoon. 'n Analise van die hemolimfmonsters het getoon dat hierdie proteien waarskynlik uit die hemolimf verkry is. In 'n vergelyking van die geïnkubeerde en kontrolehemolimf' het dit aan die lig gekom dat die konsentrasie van hierdie proteien by die geinkubeerde hemolimf aansienlik laer was, terwyl die konsentrasie van die ander hemolimfkomponente grootliks ooreengestem het. Dit moet egter beklemtoon word dat daar in die bestaande eksperiment nie onderskei kan word of hierdie proteien slegs op die oppervlak aan die sporosiste teenwoordig was en of dit ook transtegumentaal as voedsel opgeneem was nie. In laasgenoemde geval sou dit waarskynlik nie by beskerming van die sporosist betrokke wees nie, maar tog tot die oorlewing van die sporosist bydra. Deur oppervlakproteiene van die sporosiste voor en na inkubering te merk en daarna te elektroforeer, kan die posisie van die proteien onder bespreking beter bepaal word. 


\title{
'n Voorlopige analise van die flora van Stellenbosch
}

\author{
M.H. Buys, J.J.A. van der Walt en C. Boucher \\ Departement Plantkunde, Universiteit van Stellenbosch, Stellenbosch 7600
}

Die opstel van 'n kontrolelys van varings en blomplante maak dit moontlik om floristiese verwantskappe tussen taksons in die Stellenboschgebied te ondersoek en om hierdie verwantskappe met ander gebiede te vergelyk. Dit sal ook as basis dien vir die opstel van 'n Flora van Stellenbosch (FSTE).

Die analise is gebaseer op 'n kontrolelys wat opgestel is uit eksemplare gehuisves in die Distriksherbarium van die Universiteit van Stellenbosch (STEU), Stellenbosch Staatsherbarium (STE) en die Bolus Herbarium (BOL); spesies vermeld in Braun-Blanquet-tabelle van persele in die Stellenboschgebied; spesies vermeld in bestaande kontrolelyste van die gebied en spesies gelys in die Nasionale Herbarium (Pretoria) se Gerekenariseerde Informasiesisteem (PRECIS).

'n Totaal van 1800 spesies (insluitende die meeste uitheemse soorte) is tot dusver opgeteken. Die getal families, genera en spesies vir die FSTE word vergelyk met die van Hangklip, die Kaapse Skiereiland en Natal (tabel 1).

\section{TABEL 1}

'n Vergelyking tussen die getal families, genera en spesies (insluitende uitheemse soorte) in die flora van Stellenbosch (FSTE), Hangklip (HKL), Kaapse Skiereiland (KP) en Natal (N)

\begin{tabular}{|l|r|l|l|l|l|}
\hline & $\begin{array}{l}\text { Area } \\
\mathrm{km}^{2}\end{array}$ & $\begin{array}{l}\text { Getal } \\
\text { families }\end{array}$ & $\begin{array}{l}\text { Getal } \\
\text { genera }\end{array}$ & $\begin{array}{l}\text { Getal } \\
\text { spesies }\end{array}$ & $\begin{array}{l}\text { Getal spp. } \\
\text { per } \mathrm{km}^{2}\end{array}$ \\
\hline FSTE & 250 & 130 & 575 & 1800 & 7,2 \\
HKL & 240 & 110 & 430 & 1407 & 5.9 \\
KP & 471 & 129 & 702 & 2622 & 5.6 \\
N & 91385 & 179 & 1238 & 4826 & 0.05 \\
\hline
\end{tabular}

'n Analise van die FSTE word in tabel 2 gegee. Die verhouding van eensaadlobbiges tot tweesaadlobbiges vir die FSTE (1:1.93) val binne die meetgrens vir Swartboskloof (1:1.89), Kaappunt (1:1.65), die Kaapse Skiereiland (1:2.20) en Hangklip $(1: 2.0)$

TABEL 2

Analise van die flora van Stellenbosch

\begin{tabular}{|l|r|r|r|}
\hline & Familie & Genus & Spesies \\
\hline Pteridofiete & 16 & 23 & 38 \\
Getal & 12 & 4 & 2 \\
\% van totaal & 2 & 2 & 2 \\
Koniferofiete & 2 & 0 & 0 \\
Getal & 23 & 172 & 601 \\
\% van totaal & 18 & 30 & 33 \\
Liliatae & 89 & 378 & 1159 \\
Getal & & 66 & 64 \\
Magnolian totaal & 68 & 575 & 1800 \\
\hline Getal & 130 & & \\
\hline van totaal & & & \\
\hline TOTAAL & 2 & & \\
\hline
\end{tabular}

Die tien families wat die grootste getal spesies tot die FSTE bydra, word in tabel 3 geanaliseer en met families van Swartboskloof, Kaappunt, Hangklip en die Kaapse flora in tabel 4 vergelyk.

TABEL 3

'n Analise van die tien families wat die grootste getal spesies tot die flora van Stellenbosch bydra

\begin{tabular}{|l|c|c|}
\hline Familie & $\begin{array}{l}\text { Getal } \\
\text { spesies }\end{array}$ & $\begin{array}{l}\text { Getal } \\
\text { genera }\end{array}$ \\
\hline Asteraceae & 228 & 75 \\
Fabaceae & 162 & 32 \\
Iridaceae & 127 & 24 \\
Poaceae & 125 & 54 \\
Restionaceae & 82 & 13 \\
Cyperaceae & 77 & 17 \\
Ericaceae & 66 & 5 \\
Orchidaceae & 52 & 13 \\
Proteaceae & 46 & 8 \\
Scrophulariaceae & 40 & 22 \\
\hline
\end{tabular}

TABEL 4

Rangorde van families van die flora van Stellenbosch (FSTE) volgens die getal spesies ( 1 = hoogste, 10 = laagste) in vergelyking met dieselfde rangorde van families vir Swartboskloof (SBK), Hangklip (HKL), Kaappunt (KP) en die Kaapse flora (KF)

\begin{tabular}{|l|l|r|r|r|r|}
\hline Familie & FSTE. & SBK & HKL & KP & KF \\
\hline Asteraceae & 1 & 1 & 1 & 1 & 1 \\
Fabaceae & 2 & 3 & 3 & 4 & 4 \\
Iridaceae & 3 & 5 & 5 & 2 & 5 \\
Poaceate & 4 & 2 & 7 & 5 & 13 \\
Restionaceae & 5 & 4 & 4 & 6 & 7 \\
Cyperaceae & 6 & 7 & 6 & 3 & 12 \\
Ericaceae & 7 & 6 & 2 & 8 & 2 \\
Orchidaceae & 8 & 10 & 9 & 7 & 11 \\
Proteaceae & 9 & 11 & 8 & 11 & 6 \\
Scrophulariaceae & 10 & 9 & 12 & 12 & 8 \\
\hline
\end{tabular}

'n Floristiese analise van die FSTE toon dat die gebied 'n groter getal taksons besit as ander gebiede van dieselfde grootte. Die FSTE besit in vergelyking met ander gebiede die hoogste getal spesies per $\mathrm{km}^{2}$.

Die rangorde van families van die FSTE verskil nie noemenswaardig van soortgelyke rangordes van die ander vergelykte gebiede nie, behalwe dat die Poaceae en Cyperaceae van die FSTE 'n betekenisvolle hoër rangorde as dié van die Kaapse flora besit. 


\title{
Die in vitro-kultivering van Vitis vinifera. Embriokultuur en die vestiging van pitlose kultivars
}

\author{
P. Burger en I.A. Trautmann \\ Navorsingsinstituut vir Wingerdbou en Wynkunde, Privaat sak X5026, Stellenbosch 7600)
}

In die Suid-Afrikaanse tafeldruifbedryf neem die vraag na pitlose kultivars steeds toe. In die soeke na eienskappe soos beter houvermoë en vroeër of later rypwording, word 'n hoë prioriteit op die teling van nuwe kultivars by die NIWW geplaas.

In geval van pitlose kultivars is die ontwikkeling van die embrio's onvolledig en staak enkele weke na blom. Konvensionele kruisings tussen pitlose (manlike) en pithoudende (vroulike) ouers lewer dikwels 'n nageslag waarvan slegs 10 - $15 \%$ pitloos is. Onvolledige pitloosheid kom egter dikwels voor.

Die in vitro-kultivering van embrio's maak die kruising van twee pitlose ouers egter moontlik. 'n Hoër persentasie pitloosheid is ook met die in vitro-tegniek aangetoon in vergelyking met die konvensionele pitlose $x$ pithoudende kruisings. Die embrio's word "gered" deur kweking op kunsmatige medium waartydens dit in volledige plante ontwikkel.

Saadknoppe is op verskillende tye vanaf vier weke na blom uit die ontwikkelende korrel verwyder en op Nitsch \& Nitsch (1969) medium met verskillende konsentrasies en kombinasies indoolasynsuur (IAA), gibberelliensuur (GA) en bensieladenien (BA) geplaas. Na ongeveer 12 weke is van die saadknoppe oopgesny terwyl ander gelaat is om direk te ontkiem ten einde vas te stel of embrioverwydering kieming bevoordeel. Saadknoppe ("pitte") is ook weekliks oor 'n tydperk versamel en in grootteklasse verdeel om te bepaal of daar' $n$ verband is tussen groottek las en die teenwoordigheid van embrio's. Saadknoppe van Muscat Seedless is ook in vitro gekweek ten einde die kieming daarvan met dié van
Sultanina te vergelyk

Die toevoeging van plantgroeireguleerders tot die medium hel nie die kieming van die embrio's bevoordeel nie. Die verwydering van embrio's uit die saadknoppe en verdere kweking op medium het egter besliste voordele ingehou. Geen korrelasie is tussen saadknopgrootte en kieming van embrio's gevind nie, terwyl die kiemingspersentasie van Muscat Seedless embrio's hoër as dié van Sultanina was. Plantjies is ook in vitro vanaf Muscat Seedless x Centennial Seedless kruisings verkry.

'n Modelsisteem is hierna ontwerp om die sensitiewe stap van afharding van in vitro gekweekte plantjies te ondersoek. Okselknoppe van Vitis vimifera cv. Muscat Seedless is volgens 'n standaardmetode gesteriliseer en oorgeplaas na Murashige en Skoogmedium gesupplementeer met $0,1 \mathrm{~g} 11 \mathrm{~m}$-inositol, $30 \mathrm{~g}{ }^{1}$ sukrose en 0,$25 ; 1,25$ en 2,5 $\mathrm{mg} l^{\prime}$ 'bensieladenien (BA) onderskeidelik. As stollingsagente is Gelrite ( $3 \mathrm{~g} \mathrm{l}$ '),

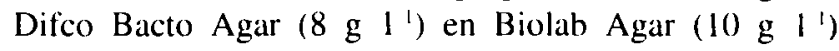
onderskeidelik gebruik ten einde die invloed hiervan op lootgroei en proliferasie vas te stel. Die in vitro gekweekte lote is hierna na bewortelingsmedium oorgeplaas wat verskillende konsentrasies indoolbottersuur (IBA) bevat. Afhardingstoestande is hierna ondersoek ten einde dié te selekteer waarby die grootste persentasie oorlewing van in vitro -saailinge voorkom. Afhardingsresultate toon dat in vitro gekweekte Vitis vinifera plantjies suksesvol afgehard kan word.

Die suksesvolle implementering van die tegniek van embriokultuur kan dus as basis dien in die pitlose tafeldruifteelprogramme in Suid-Afrika.

\section{Lokalisering van prostaglandien $\mathrm{F}_{2 \alpha}$ Oenothera stricta Ledeb ex Link}

E.G. Groenewald en A.J. van der Westhuizen

Departement Plantkunde en Genetika, Universiteit van die Oranje-Vrystaat, Posbus 339, Bloemfontein 9300

Postaglandiene (PG) is onversadigde, suuragtige lipiede met twintig koolstofatome. Hulle is farmakologies belangrik hoofsaaklik vanweë hulle fisiologiese aktiwiteit in diere. Sedert 1973, ongeveer veertig jaar na die ontdekking van prostaglandiene in diere, word die voorkoms van prostaglandiene in plante sporadies vermeld. Hoewel minder oor die aard van die fisiologiese aktiwiteit van prostaglandiene in plante bekend is, word vermoed dat die primêre werking van $\mathrm{PG}$ die regulering van membraanpermeabiliteit is. Dit is ook bevind dat prostaglandiene by blomvorming van Pharbitis nil betrokke is.
Dit is bekend dat die $\mathrm{C}_{18}$ onversadigde vetsuur, $\gamma$-linoleensuur, in relatief groot hoeveelhede in die sade van Oenothera biennis ("Evening Primrose") voorkom. Vandaar die medisinale belang van hierdie plante en selfs die aanwending daarvan vir die bereiding van sekere skoonheidspreparate. $\gamma$-linoleensuur is ' $n$ indirekte voorloper in die sinteseweg van sekere prostaglandiene ( $\gamma$-linoleensuur $\rightarrow$ dihomo- $\gamma$-linoleensuur $\rightarrow$ aragidonsuur $\rightarrow$ PG).

$O$. stricta is 'n geharde spesie wat redelik volop in versteurde grond in die Bloemfonteinomgewing voorkom. Omdat die hoë $\gamma$-linoleensuurinhoud in $O$. biennis-sade die 
vermoede laat ontstaan het dat Oenethera-spesies waarskynlik hoë prostaglandienproduseerders is, is $O$. stricta wat maklik verkrygbaar is, vir $\mathrm{PGF}_{2 \alpha}$-inhoud ondersoek. Die prostaglandiene is onderskeidelik uit die blomme, blare, sade en stingels van $O$. stricta geëkstraheer. Na skeiding op dunlaagplate is $\mathrm{PGF}_{2 \alpha}$ radio-immunologies en volgens voorskrifte met behulp van 'n "Clinical Assays"-toetsstel bepaal. Die $\mathrm{PGF}_{2 \alpha}$-inhoud van stingels en blare is onderskeidelik ongeveer tien en vier keer laer as dié in sade en blomme (0,64 $\mathrm{ng} \mathrm{g}^{-1}$ droë massa). Die hoër $\mathrm{PGF}_{2 \alpha}$-inhoud in sade hou waarskynlik verband met die teenwoordigheid van prostaglandiensintesevoorlopers wat byvoorbeeld in die sade van $O$. biennis akkumuleer. Die $\mathrm{PGF}_{2 \alpha}$-konsentrasie in die sade en blomme van $O$. stricta stem ooreen met die $\mathrm{PGF}_{2 \alpha}$ konsentrasie van die bogrondse dele van mosse en is heelwat hoër as die konsentrasie in sekere alge en plantpatogeniese swamme deur ons ondersoek. Die sade van $O$. stricta kan egter nie as hoë $\mathrm{PGF}_{2 \alpha}$-produseerders geklassifiseer word nie aangesien in ons studies met Lactuca sativa-saad tot $24 \mathrm{ng}$ $\mathrm{g}^{\prime}$ droë massa gevind is, wat veertig keer hoër is as dié in $O$. stricta. Daar moet egter in gedagte gehou word dat net vir $\mathrm{PGF}_{2 \alpha}$ getoets is en dat ander prostaglandiene teenwoordig mag wees.

\title{
Die saadbiologie van Augea capensis
}

\author{
C.A. van der Merwe \\ Departement Plantkunde, Universiteit van Stellenbosch, Stellenbosch 7600
}

Augea capensis (Thunb) is 'n plant wat tot die droër dele van Suid-Afrika beperk is. Dit is 'n geharde, sukkulente plant en kan lang tydperke van droogte oorleef. Dit produseer groot hoeveelhede saad - tot soveel as 500 kilogram per hektaar - wat gedurende lang droogtetydperke as waardevolle noodweiding dien.

Na goeie reëns is die kiemplante van $A$. capensis volop. In teenstelling hiermee ontkiem die saad van $A$. capensis nie spontaan onder laboratoriumtoestande nie. Die doelwit van hierdie ondersoek was om die oorsaak of oorsake van hierdie rus te bepaal. Tweedens is die invloed van omgewingsfaktore - lig en temperatuur in die besonder - op ontkieming ondersoek.

Saad vir die eksperimente is van die plaas Kalkgat, 80 kilometer noord van Vanrhynsdorp verkry. Ontkieming is in $9 \mathrm{~cm}$ glas Petribakkies, tussen twee lagies filtreerpapier, gedoen. Logingseksperimente is in 'n doelgeboude deurvloeisisteem gedoen. Konstante en wisselende temperature en ligtoestande is deur groeikabinette (Conviron CMP 3023 en Fisons 60063 THTL) verskaf.

Ontkieming kon nie deur die toediening van 'n verskeidenheid rusbrekende middels (gibberelliensuur, kinetien, 6bensielaminopurien, kaliumnitraat, kaliumnitriet, hidroksielamienhidrochloried, ammoniumchloried, tioureum, waterstofperoksied, kaliumsianied en natriumasied) by $A$. capensis geönduseer word nie. Chemiese skarifisering van die huid was ook onsuksesvol. Meganiese skarifisering het tot 'n geringe toename in ontkieming gelei, maar hierdie ontkieming is later as abnormaal beskryf. Wisselende temperature en verskillende substrate was ook onsuksesvol as rusbrekende metodes.

$\mathrm{Na}$ 'n tydperk van loging met water as loogmiddel, verhoog die ontkiemingspersentasie van $A$. capensis tot $94 \%$.
Tydens loging word 'n helder geel kleurstof ook uit die saadhuid en die omringende slymlaag vrygestel. Hierdie kleurstof is chromatografies van die res van die oplossing geskei en daar is gevind dat die remmende fraksie nie aan die kleurstof gekoppel is nie. Die remmende fraksie word hoofsaaklik binne die eerste 24 uur uitgeloog. Indien loging nie vinnig genoeg geskied nie, sal die sade in 'n dieper rustoestand verval.

Na die opheffing van die primêre rustoestand deur loging is gevind dat lig, hetsy konstant of as 'n enkele ligflits met 'n tydsduur van een uur, 'n remmende invloed op die ontkieming van $A$. capensis-sade het. Die sade van A. capensis word gevolglik as negatief fotoblasties beskryf. ' $n$ Enkele ligflits het eers na agt ure van donker imbibisie ' $n$ invloed op die ontkieming van $A$. capensis-saad. Dit dui op die moontlike betrokkenheid van fitochroom as die fotoreseptor verantwoordelik vir die ligreaksie teenwoordig by die sade van $A$. capensis.

Verskillende temperatuurregimes tydens die ontkieming van $A$. capensis-saad toon dat $A$. capensis-saad die beste in die reeks $10^{\circ} \mathrm{C}$ tot $30^{\circ} \mathrm{C}$ ontkiem. Hierdie temperatuurreeks korelleer met die omgewingstemperature tydens die reënseisoen in dié plant se verspreidingsgebied.

Indien daar aanvaar word dat die voortsetting van 'n plantgemeenskap afhanklik van die voortplantingsvermoëns van die individue van daardie gemeenskap is, moet die saadrus teenwoordig by $A$. capensis as 'n ekologies gevorderde eienskap beskou word. Die voorvereiste van loging en die reaksie van die saad op lig en temperatuur tydens ontkieming, is verdere bewys dat die saad in staat is om omgewingsfaktore te monitor om sodoende te verseker dat die saad slegs onder geskikte (optimale) toestande sal ontkiem. 


\title{
Taksonomie en filogenie van Pelargonium, seksie Campylia (Geraniaceae)
}

\author{
J.J.A. van der Walt
}

Departement Plantkunde, Universiteit van Stellenbosch. Stellenbosch 7600)

J.P. Roux

Nasionale Botaniese Instituut, Privaat sak X7, Claremont 7735
In die laaste taksonomiese hersiening van die seksie Campylia van Pelargonium wat in 1988 gepubliseer is, word sewe spesies erken. Sedert hierdie hersiening het die volgende drie spesies onder die aandag gekom vir moontlike insluiting in die seksie Campylia: Pelargonium incarnatum (L'Hérit.)Moench wat vroeër in die genus Erodium geplaas is, P. ocellatım J.J.A. v.d. Walt wat as 'n nuwe spesie ontdek en beskryf is, en $P$. setulosum Turcz. wat vroeër in die seksie Ligularia geklassifiseer is.

Die eerste doelwit met die studie was om te bepaal of bogenoemde drie spesies in die seksie Campylia geplaas behoort te word. Die tweede doelwit was om deur middel van 'n kladistiese ontleding 'n hipotese op te stel oor die filogenie van die spesies in die seksie Campylia.

Om die eerste doelwit te bereik, is die volgende kenmerke van $P$. incarnatum, $P$. ocellatum en $P$. setulosum met dié van die bestaande seksie Campylia vergelyk:

Habitus: Die seksie Campylia bestaan uit kruidagtige halfstruike met kort hoofstamme. Kloonpopulasies waar die plante ondergronds deur middel van risome met mekaar in verbinding is, kom dikwels voor. Al hierdie kenmerke word by die drie spesies aangetref.

Blare: Die blare van spesies van die seksie Campylia is handvormig tot veervormig verdeel. Die blare van die drie spesies is baie eners en toon groot ooreenkomste met dié van die seksie Campylia.

Blomme: $\quad$ In P.caespitosum Turcz. en P.ovale (Burm.f.) L'Hérit. (seksie Campylia) is die agterste twee kroonblare opvallend groter as die voorstes. In al die ander spesies van die seksie Campylia, en in $P$. incarnatum, $P$. ocellatum en $P$. setulosum is die agterste en voorste kroonblare min of meer ewe groot. Swart, vratagtige kolle kom op die agterste kroonblare van $P$. capillare (Cav.)Willd., P. tricolor Curt. (seksie Campylia) en P. ocellatum voor. Die aantal vrugbare meeldrade varieer van vyf tot sewe in die seksie Campylia. P. incarnatum en $P$. setulosum het elk vyf vrugbare meel- drade, terwyl $P$. ocellatulı sewe het. In $P$. caespitosum en $P$. ovale is c.e hipantiums baie gereduseer. 'n Soortgelyke gereduseerde hipantium kom ook in $P$. incarnatum voor.

Stuifmeelmorfologie: Die stuifmeelkorrels van seksie Campylia is sferies met 'n pooldeursnee van $49-83 \mu \mathrm{m}$. Hulle is trikolporaat met netvormige tot netvormig gestreepte tektums. Die stuifmeelkorrels van $P$. incarnatum, $P$. ocellatum en $P$. setulosum is ook sferies en trikolporaat met 'n pooldeursnee van 60-70 $\mu \mathrm{m}$ en netvormig gestreepte tektums.

Chromosoomgetalle: Die basiese chromosoomgetal van seksie Campylia is $\mathrm{x}=10$ en somatiese chromosoomgetalle van $2 n=20 \& 40$ is bekend. $P$. ocellatum het 'n somatiese chromosoomgetal van $2 \mathrm{n}=20$, en $P$. incarnatum en $P$. setulosum $2 \mathrm{n}=40$. Die chromosoomgrootte van seksie Campylia en die drie spesies is identies.

Die habitus, blaarmorfologie, blomkenmerke, stuifmeelmorfologie en chromosoomgetalle dui dus daarop dat $P$. incarnatum, $P$. ocellatum en $P$. setulostun in die seksie Campylia geplaas behoort te word. Nieteenstaande die aansienlike variasie in blomkenmerke word die seksie Campylia sensu lato as 'n natuurlike takson beskou. Die variasie in blomkenmerke kan waarskynlik aan verskillende bestuiwingstrategieë toegeskryf word.

Natuurlike hibriede tussen die seksies Campvlia, Glaucophyllum Harv. en Pelargonium dui daarop dat hulle naverwant is. Al drie seksies word gekenmerk deur relatiewe klein chromosome. Die blom- en blaarkenmerke van $P$. elegans (seksie Campylia) vertoon baie ooreenkomste met dié van P. betulinum (L.)L'Hérit. (seksie Pelargonium). Die seksie Pelargonium word beskou as die seksie met die meeste plesiomorfiese kenmerke in die genus. Om hierdie rede is $P$. betulimum as 'n moontlike voorvaderlike spesie gekies tydens die kladistiese analise van die seksie Campylia.

Vir die kladistiese analise is daar van die Farris HENNIG 86-program gebruik gemaak. Elf kenmerke, elk met twee kenmerkstate, is vir die kladistiese analise gebruik. 